\title{
Analysis on the Compensation System of Marketing Personnel of Building Material Enterprises under the Background of the Sponge City
}

\author{
Yihang LV \\ Chengdu Neusoft University, Chengdu 611844, Sichuan, China
}

Keywords: sponge city; marketing personnel; compensation system.

\begin{abstract}
With the reform and opening of our country and the leadership of the Party Central Committee with general secretary Xi as the core, China's economy has achieved rapid development, which has attracted the attention of the world. Under the background of the sponge city, this paper takes one building material enterprise for example, through the research of company's compensation system, summarizes the related issues of this company, analyses the issues to get the optimization strategy of company compensation, and wish to propose improvement measure of compensation system of marketing personnel of building material enterprises under the background of the sponge city.
\end{abstract}

\section{Introduction}

With the reform and opening of our country and the leadership of the Party Central Committee with general secretary $\mathrm{Xi}$ as the core, China's economy has achieved rapid development and attracted the attention of the world. Under this environment, people's ideas show a trend of diversification, and it causes great changes occur in people's needs. The traditional compensation system cannot meet the needs of enterprise personnel, and it doesn't encourage personnel. Similarly, as country proposes concept of the sponge city, the compensation system of marketing personnel of traditional building material enterprises have been unable to adapt to the social development and market competition, this paper mainly takes one environmental protection building material enterprise A for example and studies the compensation system of marketing personnel of building material enterprises under the background of the sponge city.

\section{Background Information}

The sponge city is a new generation of city rain-flood management concept, and it is referring to the city with good "flexibility" in adapt to environmental changes and deal with natural disasters brought about by the rain, which can also be called "water elasticity city". The international common term is "low impact development rainwater system construction". When it rains, it absorbs water, stores water, permeates water and purifies water, and "release" the stored water and use it when needed.

General Secretary Xi Jinping clearly proposed in the work conference on central urbanization in 2013: give priority to considering leaving limited rain when improve city drainage system, give priority to using more natural forces to drain off water, and construct the "sponge city" with natural accumulation, natural infiltration, and natural purification.

On October 11, 2015, the General Office of the State Council issued a guideline on promoting the construction of the sponge city (issued by General Office of the State Council 2015 [2015] No.75).

On March 5, 2017, in the 5th conference of the 12th the National People's Congress (NPC) of the People's Republic of China, Premier Li Keqiang mentioned in the government work report: plan city over ground and underground construction as a whole, more than 2000 kilometers of underground comprehensive pipelines will be built., start to eliminate the key waterlogging areas of urban area three years action, promote the construction of the sponge, and make city have "face", more have "inside". 
In this context, the national pilot sponge cities are more and more, the construction projects are more and more, this is a huge emerging market for building material enterprises. How to stand out from numerous enterprise competitions; which is a huge problem for every building material enterprise. At this time, the role of enterprise marketing personnel is particularly crucial in the competition, and the compensation system design of marketing personnel has played an important role.

\section{Analysis of Compensation System of Traditional Building Material Enterprises -- Taking Company A as An Example}

\subsection{Overview of Company A and Current Situation of Compensation Management}

A company was founded in November 2010, which has 20 years of experience in mold research and development, and it mainly produce plastic pipe and fittings, valves, faucets and other products, for the research and development of plastic check inspection shaft, accumulation of professional technical personnel, mold research and development experience, production equipment and so on. The plastic products as the main, its product combinations mainly include plastic inspection well, sewage treatment series, plastic valve series, drainage pipeline series and so on, has application in underground drainage, product combinations are perfect, and effectively formulate, choose appropriate competitive products as the main product, create higher profits in the product combinations, create suitable space for its product operation, product research and development, production equipment, personnel allocation, financial operations and so on, can effectively save the cost of production and operation, consolidate maintenance and growth of market position and market share. At present, the enterprise's compensation system for marketing personnel is simply divided into income $=$ basic compensation + sales bonus. The basic wages include regular wage, seniority wage, oil card subsidy, communication fee, etc, the basic wage of marketing personnel who have worked for 2 years is between 4000 and 5000 Yuan, the sales bonus is three percent of the simple sales revenue. The average per capita task is around 3 million in the company's current marketing personnel. Throughout this year, the income of marketing personnel who complete the task can reach between 140,000 and 150,000 Yuan.

\subsection{Main Problems of Company Compensation}

\subsubsection{The Company Does Not Pay Enough Attention to the Compensation Management of Marketing Personnel}

The company lacks enough understanding and attention to the compensation system of marketing personnel from the decision-making level to management. The compensation system of marketing personnel is not included in the long-term planning and construction of the enterprise. The work income of marketing personnel is simply divided into basic wage and sales bonus.

\subsubsection{Non-Material Compensation is Less}

The company only gives the marketing personnel the material incentive, lacks the management of sales personnel from spirit incentive angle. Because the company neglect non-material giving for long, the personnel ' spiritual and cultural life is relatively lacking, which has caused a lot of obstacles to the operation and development of the enterprise.

\subsubsection{The Setting of Sales Bonus is Not Scientific Enough.}

At this stage, the company's sales bonus is simply set as $3 \%$ of the sales revenue. If a salesperson is easily satisfied with own needs, he only hopes to get 30,000 Yuan bonuses, then he can sell one million Yuan at this time. Under this setting, the marketing personnel management and incentive function are not obvious enough and remains to be adjusted and optimized.

\subsubsection{Compensation Level Classification is not Enough}

At present, the company's compensation level and step are relatively small; the difference is not obvious from the income of marketing personnel who have just entered the company and have worked three or five years, this is extremely unfavorable to retain good marketing talents. 


\section{Improvement Strategy of Company Compensation Management}

\subsection{Compensation Management Needs Innovation}

The reform and innovation of the company's compensation is not only the need of the enterprise itself, but also in order to adapt to the emergence of the new background of the sponge city. Traditional compensation system, in particular, the compensation system of the marketing personnel needs reform and innovation. Company must under the principle of "people-oriented" and "effective incentive", break through the traditional compensation management system with basic compensation and sales bonus, set up the modern compensation management concept. Making the compensation system not only see the combination of benefits, but also according to the marketing personnel's own needs, grasp the incentive effect on personnel. The combination of long-term incentive and short-term incentive are done well, and eventually form an effective incentive system.

\subsection{Optimize the Compensation Management Mode and Management Principles}

The company needs to establish the idea of "humanistic management" under the principle of fairness, justice, publicity, fully respect the marketing personnel's vital interests and feeling basis, and design the marketing personnel's compensation system. Taking company A as an example, the structure of basic compensation can be further optimized according to the historical contribution of personnel. The setting of sales bonus can be further optimized. The original is set to three percent of sales revenue, and adjust to set a threshold, if sales with 1 million are less than three percent, sales reach 2 million and will increase to four percent, and so on. Through the above bonus step deduction, further improve the marketing personnel's enthusiasm, promote the marketing personnel to do more achievement quantity, and it has great benefits for the enterprise operation and development.

\subsection{Supplement and Perfect Non-Material Payment}

According to Maslow's hierarchy of needs, In addition to the material needs, people have more demand. Then it is the same for marketing personnel. In addition to providing the marketing personnel with material payment, it should supplement and improve the non-material nature. For example, the excellent marketing personnel can be compared and appraised every year. Set up the sales achievement award, the fastest progress award and other awards. Trophy and citation will be given to the winners, and publicity and promotion will be carried out on the official website of the enterprise. This can give the marketing personnel spirit incentive except material incentive. In addition to improving personnel' enthusiasm, it can also increase personnel' enterprise loyalty and bring personnel together.

\subsection{Consider Option and Equity Incentive Timely}

The enterprise can give option or equity to marketing personnel who have worked for many years in accordance with the actual situation, especially give an option or equity to good marketing management. Let the personnel become the owners of the enterprise from the workers; really participate in the operation and management of the enterprise, thus improving the stability and competitiveness of the team.

\section{Conclusion}

This paper takes one building materials enterprise A for example under the background of the sponge city, with some, for example, studies through the company's compensation system, summarizes the related issues of this company, and analyses the problem to get the optimization strategy of the company compensation. Predictably, with the continual pilot and promotion of the sponge city construction, the building material enterprises as the biggest beneficiaries, they will also pay more attention to enterprise compensation management work, especially the marketing personnel's compensation management system. The construction of the compensation system of the marketing personnel of China's building material enterprises will be more scientific, standardized and sustainable. 


\section{Acknowledgements}

Phased achievements of the major projects of humanities and social science in the Education Department of Sichuan in 2018, project number.

\section{References}

[1]. Liu Hua. Compensation Management[M], Dalian: Dongbei University of Finance \& Economics Press, 2011:142-144.

[2]. Yu Man. Enterprise compensation design program and scheme [N], Human Resources and Development of China, 2013.

[3]. Li Zhichou. Compensation system design and management practice [M]. Phoenix Publishing House, 2014:30-120.

[4]. Tudor, Thomas R, Trumble, Robert R. The Changing Pattern of Pay and Benefits, Journal of Compensation \& Benefits, 2008, (5):22-30. 